\title{
Evaluation of the behavior of the preschool one just admitted in the unit of pediatrics and the use of the therapeutic toy
}

\author{
A avaliação do comportamento do pré-escolar recém-admitido na unidade de pediatria e 0 \\ uso do brinquedo terapêutico
}

\author{
Mariana Coelho Campos ${ }^{1}$, Karen Cristina S. Rodrigues ${ }^{2}$, Marcia Carla Morete Pinto ${ }^{3}$
}

\begin{abstract}
Objective: To evaluate the behavior of children before and after a therapeutic play session. Methods: A quantitative and descriptive study was carried out in a major hospital of the city of Santos, State of São Paulo, involving 30 preschool children recently admitted to a pediatric ward. A behavior scale was applied before and after a therapeutic play session. This scale comprises six categories: moving, gazing, expressing feelings, talking, playing, and not responding to stimuli or requests. Each category is scored from 1 to 3 , the lowest score representing the least interaction. Results: Before therapeutic play sessions, children showed no interest and were scored 1 and 2: moving parts of their bodies and expressing emotions, such as seriousness, and gazing rapidly to a place as if expecting something. After therapeutic play, the children progressed to level 3: changing position, moving with a purpose, observing attentively to what they saw, and expressing emotions such as joy. Conclusion: Children interact well with the toys, representing home and hospital situations, and expressing feelings of anger and love. We also observed that therapeutic play improved the interactions of children with this new situation, making it easier for them to accept treatment and perceiving hospitalization as less aggressive and painful.
\end{abstract}

Keywords: Play and playthings; Play and playthings/ psychology; Child, preschool; Pediatric nursing/methods; Child, hospitalized; Patient admission; Behavior and behavior mechanisms; Emotions

\section{RESUMO}

Objetivo: Avaliar o comportamento da criança antes e depois da sessão de brinquedo terapêutico. Métodos: Este estudo é de natureza quantitativa e descritiva, e foi realizado em um hospital de porte extra no município de Santos, Estado de São Paulo. Foi desenvolvido com 30 crianças pré-escolares recém-admitidas na unidade pediátrica, às quais foi aplicada uma escala comportamental antes e depois da sessão de brinquedo terapêutico. Essa escala abrange seis categorias: movimentar, olhar, expressar emoções, verbalizar, brincar e a última, na qual a criança não responde ao estímulo ou à solicitação. Cada categoria apresenta três níveis (1, 2 e 3) e quanto menor o nível, pior a interação da criança nesse novo momento. Resultados: Antes da sessão de brinquedo terapêutico, as crianças não mostravam interesse, foram encaixadas dentro dos níveis 1 e 2: movimentar parte do corpo e expressar emoções, como seriedade, dirigir o olhar a um local rapidamente como se estivessem esperando algo. Depois da sessão de brinquedo terapêutico, as crianças migraram do nível 1 para o nível 3, no qual mudavam de posição, deslocavam-se com uma finalidade, observavam atentamente o que viam e expressavam emoções, como alegria. Conclusões: A criança interage bem com o brinquedo, dramatizando situações domésticas e hospitalares, manifestando sentimentos de raiva e amor. Observou-se também que a sessão de brinquedo terapêutico propicia melhor interação da criança com esse novo momento que está vivendo, aceitando mais facilmente o tratamento e enxergando de forma menos agressiva e dolorosa sua hospitalização.

Descritores: Jogos e brinquedos; Jogos e brinquedos/ psicologia; Pré-escolar; Enfermagem pediátrica/métodos; Criança hospitalizada; Admissão do paciente; Comportamento e mecanismos comportamentais; Emoções

\section{INTRODUCTION}

Toys are the child's universal language; they provide them with a means to put their feelings into words, especially in difficult situations, rather than using other less acceptable forms of emotional expression. They are thus particularly indicated for children with limited language abilities, providing them with a means of expressing themselves freely ${ }^{(1-3)}$.

Final paper presented at Universidade Metropolitana de Santos - UNIMES, Santos (SP), Brazil (2008).

Study carried out at Unidade de Pediatria da Universidade Metropolitana de Santos - UNIMES, Santos (SP), Brazil.

1 Undergraduate student, Universidade Metropolitana de Santos - UNIMES, Santos (SP), Brazil.

2 Undergraduate student at Universidade Metropolitana de Santos - UNIMES, Santos (SP), Brazil.

${ }^{3}$ Master's degree; Lecturer at Universidade Metropolitana de Santos - UNIMES, Santos (SP), Brazil.

Corresponding author: Marcia Carla Morete Pinto - R Pres. Artur Bernardes, 23/72 - Embaré - CEP 11040180 - São Paulo (SP), Brasil - Tel.: 13 3273-7009 - e-mail: marciamorete@uol.com.br

Received on June 12, 2009 - Accepted on Dec 11, 2009 
These attributes of play are based on the origin of the word "play" itself, in which we find an explanation for its integrating function ${ }^{(4)}$. The etymology of the word "play" demonstrates how essential ludic activities are for child development; in other words, children play from an early age to integrate themselves with their own selves, with others and with the environment ${ }^{(5)}$.

The socialization period ranges from three to five years old (pre-school). Play is enriched by social and language development, increased knowledge and attention ability, and improved motor coordination. The most important feature in this phase is free imagination, a special ability in pretend and make believe (bad guy versus good guy; ballet dancer, teacher, kung-fu, etc.). Another important figure of this phase is an "imaginary friend," more often seen in children with no siblings and who have little contact with other children.

Toys are objects children use in their play; they have no rules, different from games. Children may handle toys only or use them in make believe play ${ }^{(5)}$.

Child play has been studied by several professionals from different areas of knowledge, especially in healthcare and education. Increased knowledge supported several scientific studies that allowed us to uncover the mysteries of child play. Children express symbolically their fantasies, desires and experiences ${ }^{(6)}$.

Within the various forms of play, therapeutic play has been of significant interest to nurses, who carried out several studies and noted certain trends in this area. Many of these researchers in pediatric nursing referred to the importance of understanding play as an essential aspect of nursing care for children. Among these, Whaley and Wong showed that play is the work of children; it is an essential activity for their mental, emotional and social well-being and, like other developmental needs, does not cease when a child becomes ill and is admitted to a hospital ${ }^{(2)}$.

Hospital admittance is a highly stressful and traumatic experience for children, as it involves an abrupt change of their setting. Children find themselves in an alien environment without knowing what will happen; this generates fear, insecurity and anxiety ${ }^{(7)}$.

Preschool children have a limited understanding of facts and situations they experience, because of their egocentric and fantasy thinking ${ }^{(8)}$. When hospitalized, children find it difficult to understand what is going on, both with regards to the disease itself and the diagnostic and therapeutic procedures; they thus find it difficult to interact with their diseased body ${ }^{(9)}$.

Considering that one of the basic principles of nursing is to care for people as a whole - caring for a person rather than just a disease - a special focus should be given to the child's need for play, which becomes part of nursing care ${ }^{(10)}$.
Nurses in Brazil have not employed therapeutic play very often, although recent studies have shown a growing interest in using play in nursing work ${ }^{(11-18)}$. It should be noted that therapeutic play has always been present in nursing. Florence Nightingale was the first nurse to comment on this in the second edition of her book "Notes on Nursing", originally published in 1961 and translated into Portuguese in 1989; it includes a section on children, recognizing them as different from adults, with their own health needs, such as the need to play, which was considered essential for their recovery ${ }^{(19)}$.

Therapeutic play aims to help preparing children for therapeutic procedures and to allow them a means to dissipate their stress about such procedures by representing their experiences and handling medical instruments or toys that represent these instruments ${ }^{(20-21)}$.

Therapeutic play has four basic aims:

- recreation, whose main purpose is to be pleasure and distraction;

- stimulation, to naturally foster motor/sensory, intellectual and social development, as well as creativity;

- socialization, as children may experience social roles and learn to relate with others;

- catharsis, in which children may represent roles and conflict, expressing their feelings and conflicts to decrease anxiety ${ }^{(22)}$. Therapeutic play is structured to help children dispel the anxiety originating from atypical and potentially threatening experiences for their age, which may require more than the usual recreational play ${ }^{(23)}$.

Therapeutic play may be classified into three types: - dramatic or cathartic play for emotional discharge; children express their feelings, fantasies, desires and experiences; bring out internalized social relations and roles; communicate effectively with adults; criticize their milieu and family relations; become active rather than passive; take on social roles, pretend being mother, father, and professionals; strengthen their ego; attain behavioral change; and "purify their souls;"

- instructional play, which aims to explain procedures to children so that they may know what to expect and how to participate during medical procedures; understanding the purpose of procedures, becoming involved rather than merely a passive object; handling the material before and after the experience; establishing a relationship of trust in adults and professionals;

- enabling play for physiological functions, training for using functions according to the biophysical 
status, for instance, children depending on artificial respirators or oxygen catheters; preparing children for fully applying their physiological abilities within their possibilities, to accept new living conditions; also using simulated or real materials or equipment.

Several Brazilian authors demonstrated how hospitalized children have been supported by therapeutic play in nursing care, helping to communicate and relate with children, learning about their feelings and concerns, helping dispel their stress, and preparing children for unpleasant procedures, including surgery ${ }^{(7,9,14,24-25)}$.

Ribeiro applied therapeutic play in preschool children in the first two days of hospital admittance and found that these children had behaviors more compatible with their development, with stronger ego and adaptation compared to the children not participating in therapeutic play ${ }^{(11)}$. His doctoral thesis included interviews with play to understand the meaning of interactions experienced by preschool children during hospital stay; it also brought up the pain children felt because of the disease and invasive procedures, as well as their lack of understanding of events and their efforts to face pain in the company of their mothers ${ }^{(11)}$.

Therapeutic playsessionswere donewith hospitalized preschool children; it was observed that play facilitated expression of feelings, emphasizing the importance of an adult nearby to accept and encourage such expression. It was also noted that a single play session improved the effectiveness of contact with children ${ }^{(7)}$.

Nurses have used therapeutic play with hospitalized children not only for recreational purposes and physical, emotional, mental and social development needs, but also for giving explanations and receiving information about the meaning of situations for them ${ }^{(18)}$.

Based on these considerations, we wished to investigate whether therapeutic play would change the behavior of children and facilitate their adaptation to hospitalization.

\section{OBJECTIVE}

The purpose of this study was to assess the behavior of preschool children recently admitted to a pediatrics unit, before and after a therapeutic play session.

\section{METHODS}

We conducted a quantitative, descriptive study of primary data. The study area was the pediatrics unit of a major general and teaching hospital. The study population comprised 30 preschool children aged from 3 to 6 years admitted to the pediatrics unit during the data-gathering period. A data sheet and questionnaire was filled in with information about each child, and the evaluation was based on a behavioral scale ${ }^{(11)}$, adapted by the researchers for observing and recording the behavior of children before therapeutic play. The scale consisted of six categories: moving, gazing, expressing emotions, talking, playing, and lack of responses to stimuli or requests. Each category was scored from 1 to 3 ; each level characterized specific behavioral aspects of children. Therapeutic play sessions were conducted to enable children to represent domestic and hospital situations, to express anger and hostility, regression feelings, as well as free expression through drawings and construction. Data were recorded in the specific questionnaire, after which a new evaluation was done with the same behavioral tool.

The research project was forwarded to the pedagogical coordinating department and the Institutional Review Board of Universidade Metropolitana de Santos for approval. Authorization was given for gathering data at Irmandade da Santa Casa de Misericordia de Santos by means of a researcher compliance form which was forwarded to the nurse in charge of the pediatrics unit of the National Unified Health System.

The behavioral scale was evaluated based on observations of children, where behaviors were noted in several categories, as mentioned above. Before this procedure, the researchers observed the children for 20 minutes, after explaining the purpose of the study to parents. Upon their consent, the therapeutic play session was started, beginning at the bed and guiding each child during the session (20 minutes); they were also asked not to take any toy with them. During the therapeutic play session, the researchers left each child free to choose the toys they wanted to play with. The researchers observed and recorded the behaviors in each procedure, as described in Appendix A.

The following basic principles underlined the technique used in therapeutic play sessions:

- children were invited to play and toys were offered in a bag;

- before starting to play, children were told that they could play as they wished, but the toys would be gathered and placed back in their boxes;

- they were also told that the researchers would write things down during play;

- the researchers remained close to children, acting non-directively, observing without interfering and participating only when asked, always allowing the children to play freely and unhurriedly; 
- toys were not named by adults and questions were asked back to children;

- non-verbal behaviors of children were not reflected back to them or explained by the researchers, who also did not suggest that children were talking about themselves, since this was not a ludotherapy session.

The groups of toys were selected based on studies by Angelo $^{(9)}$ and Ribeiro ${ }^{(11)}$, to which others that represented the materials used in a hospital setting were added: figures representing hospital teams (physicians and nurses), hospital objects (syringes, saline solution flasks and lines, dressing tape, scalpels, cuffs, stethoscopes, gloves, gauze, vesical catheters, flasks, cannules, dressings, among others), household objects (plates, cutlery, cups, pans, bowls, dolls, chairs, toy guns, toy cars, among others), and others, as shown in figures 1 and 2. The dolls were flexible and their clothes could be removed so that children could handle them more easily.

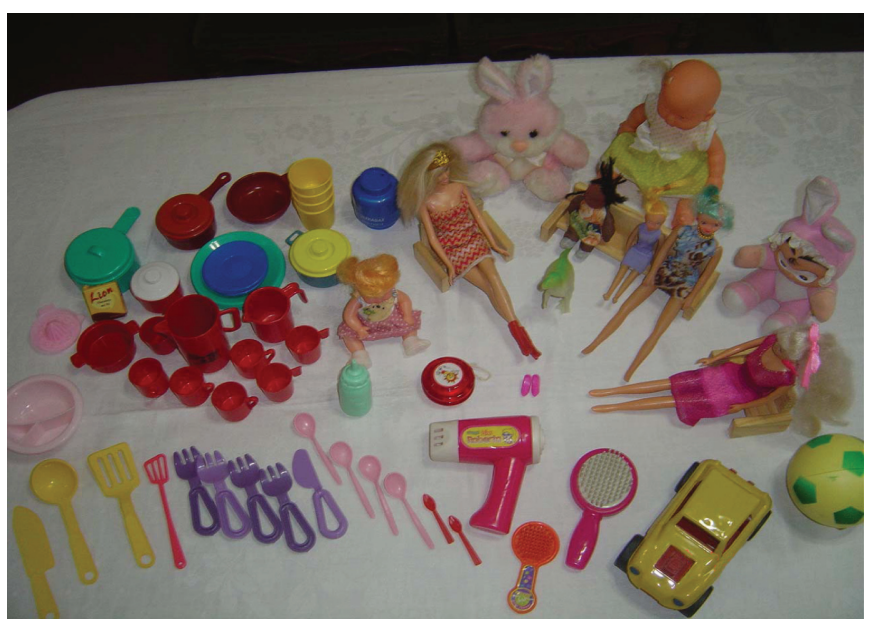

Figure 1. Daily use toys employed in the therapeutic play session, Santos, 2006.

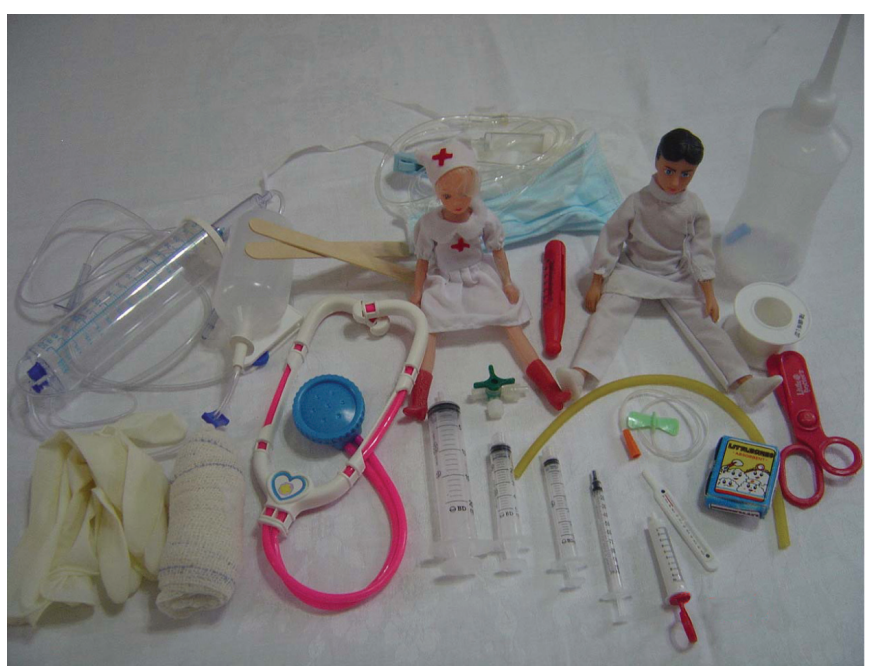

Figure 2. Hospital toys used in the therapeutic play session, Santos, 2006.

\section{RESULTS}

Data were analyzed quantitatively based on descriptive statistical techniques; answers were grouped according to the frequency of levels 1,2 and 3 and presented in figures 3 to 6 , containing absolute and relative numbers.

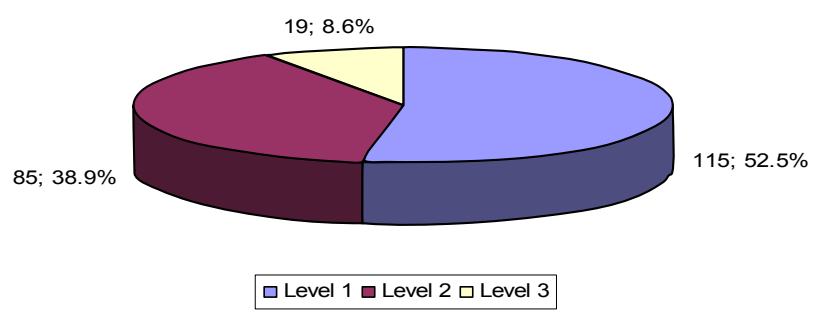

Figure 3. Distribution of behavior levels identified in children before therapeutic play session, Santos, 2006.

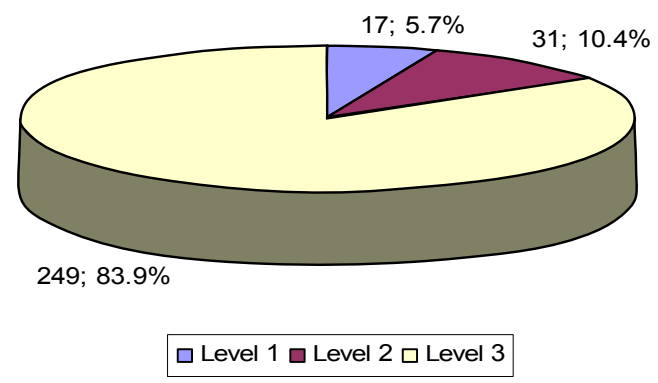

Figure 4. Distribution of behavior levels identified in children after therapeutic play session, Santos, 2006.

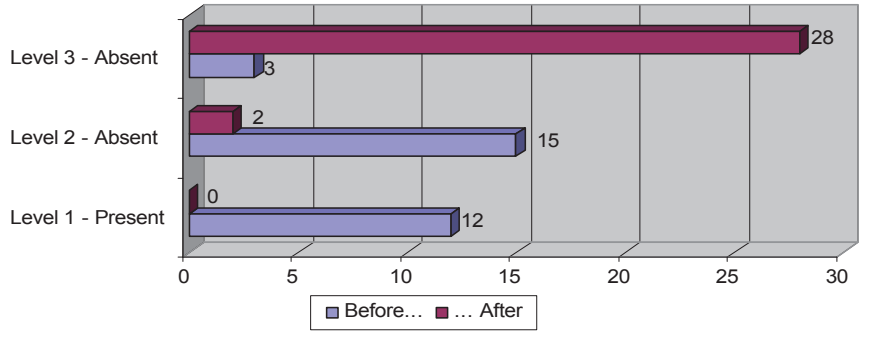

Figure 5. Distribution of children admitted to the Pediatrics Unit as to no responding to stimuli and requests before and after therapeutic play session, Santos, 2006.

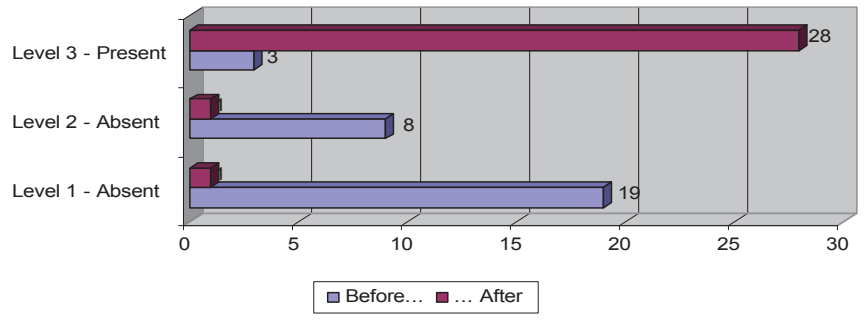

Figure 6. Distribution of children admitted to the Pediatrics Unit as to no playing before and after therapeutic play session, Santos, 2006. 
The scale comprises six categories: moving, gazing, expressing feelings, talking, playing, and not responding to stimuli or requests. Each of these six categories contained different actions classified into three response levels varying progressively from the level 1 (actions with more dependency, passivity and less interaction with other subjects), to levels 2 and 3 (actions showing gradually increasing levels of independence, participation and interactions with other subjects).

There were 30 children in this study, of which 11 $(37 \%)$ were 3 years old, 7 (23\%) were aged from 4 to 5 years, and $5(17 \%)$ were 6 years old. There were 17 male $(57 \%)$ and 13 female $(43 \%)$ children.

The number of behaviors or sub-categories observed before the therapeutic play session was 219 (100\%). A significant part of the sample presented level 1 (115; $52.5 \%)$ and $2(85 ; 38.9 \%)$ behaviors, which describe poor adaptation attitudes; there were only 19 (8.6\%) level 3 behaviors (Figure 3 ).

Figure 4 shows the results after the therapeutic play session; children showed more behaviors (297), most of which were level 1II (84\%), showing that therapeutic play may result in adjusting and less stressful behaviors for children. There were still 31 level 1 behaviors (10\%) and 17 level 2 behaviors (6\%).

Before the therapeutic play session, 12 children were at level 1, that is, they did not respond to stimuli or requests; half were at level 2 (responders), and 3 children responded with level 3, showing some reaction to stimuli and requests. Figure 5 also shows that, after the therapeutic play session, these numbers are reverted; most of the children presented level 3 responses, with improved reactions to stimuli and requests.

Figure 6 shows that most of the children did not play before the therapeutic play session; after the therapeutic play session, however, play acting was more evident, although there were still a few children that were not ready to play.

Tables 1, 2 and 3 show the distribution of level 1, 2 and 3 actions in children before and after the therapeutic play session. Behaviors were broken down to analyze subcategories within the total number of behaviors.

Most of the behaviors were level 1; the most frequent among these was "moving part of the body" ( 24 children), followed by handling clothes and objects ( 6 children). In the category "gazing", the most frequent action was looking quickly at a specific place (12 children) and gazing without demonstrating true visual contact (5 children). In the category "expressing emotions", seriousness was the most frequent emotion (16 children), followed by sadness ( 9 children). In "talking", children issued sound and words without meaning (4 children), talked to themselves and expressed the desire to leave the hospital (1 child) (Table 1).
Table 1. Distribution of level 1 actions identified in children before and after therapeutic play session, Santos, 2006

\begin{tabular}{|c|c|c|}
\hline Behaviors & Before & After \\
\hline \multicolumn{3}{|l|}{ Moving } \\
\hline Moving part of the body & 24 & 1 \\
\hline Changing position and walking without purpose & 1 & 0 \\
\hline Handling clothes and objects & 6 & 1 \\
\hline Sucking & 1 & 0 \\
\hline \multicolumn{3}{|l|}{ Gazing } \\
\hline Looking quickly at a specific place & 12 & 1 \\
\hline Gazing without demonstrating true visual contact & 5 & 1 \\
\hline \multicolumn{3}{|l|}{ Expressing emotions } \\
\hline Looking sad & 9 & 4 \\
\hline Apathy & 4 & 1 \\
\hline Seriousness & 16 & 5 \\
\hline \multicolumn{3}{|l|}{ Talking } \\
\hline Talking to themselves & 1 & 0 \\
\hline Sound and words without meaning & 4 & 1 \\
\hline Say they want to leave & 1 & 1 \\
\hline \multicolumn{3}{|l|}{ Playing } \\
\hline Absent & 19 & 1 \\
\hline \multicolumn{3}{|l|}{ Not responding to stimulus or requests } \\
\hline Present & 12 & 0 \\
\hline Total of behaviors & 115 & 17 \\
\hline
\end{tabular}

Table 2. Distribution of level 2 actions identified in children before and after therapeutic play session, Santos, 2006

\begin{tabular}{|c|c|c|}
\hline Behaviors & Before & After \\
\hline \multicolumn{3}{|l|}{ Moving } \\
\hline Performing actions to obey orders & 7 & 2 \\
\hline Moving in the room following somebody & 3 & 2 \\
\hline Changing position & 9 & 4 \\
\hline Moving to look something & 3 & 1 \\
\hline \multicolumn{3}{|l|}{ Gazing } \\
\hline Look following someone or something moving & 12 & 7 \\
\hline $\begin{array}{l}\text { Demonstrating to keep visual contact with somebody } \\
\text { or something, but with no reaction }\end{array}$ & 2 & 1 \\
\hline \multicolumn{3}{|l|}{ Expressing emotions } \\
\hline Sadness with cry & 4 & 0 \\
\hline \multicolumn{3}{|l|}{ Talking } \\
\hline Talking fast and in a low volume & 3 & 0 \\
\hline Answering to question in a low volume & 18 & 9 \\
\hline Mentioning parents but not completing thoughts & 0 & 1 \\
\hline Answering that desires to play alone & 0 & 1 \\
\hline \multicolumn{3}{|l|}{ Playing } \\
\hline Absent & 9 & 1 \\
\hline \multicolumn{3}{|l|}{ Not responding to stimulus / requests } \\
\hline Absent & 15 & 2 \\
\hline Total of behaviors & 85 & 31 \\
\hline
\end{tabular}

Before the therapeutic play session, children were not encouraged to play at the hospital facilities; after the therapeutic play session, although such behavior was not observed, we found that children remained tense and apathic with regards to the hospital environment. 
Table 3. Distribution of Level 3 actions identified in children before and after therapeutic play session, Santos, 2006

\begin{tabular}{|c|c|c|}
\hline Behaviors & Before & After \\
\hline \multicolumn{3}{|l|}{ Moving } \\
\hline Changing position & 2 & 25 \\
\hline Moving in the room with a purpose & 0 & 17 \\
\hline Performing actions with defined objectives & 0 & 13 \\
\hline $\begin{array}{l}\text { Performing physiological movement voluntarily, and } \\
\text { satisfaction of a need }\end{array}$ & 1 & 0 \\
\hline \multicolumn{3}{|l|}{ Gazing } \\
\hline Fixed their eyes on someone or something & 1 & 19 \\
\hline Carefully observed what they see & 3 & 25 \\
\hline Look and present reaction to what they see & 0 & 7 \\
\hline Looks at the parent to answer & 0 & 1 \\
\hline \multicolumn{3}{|l|}{ Expressing emotions } \\
\hline Happiness & 2 & 22 \\
\hline Laugh & 0 & 14 \\
\hline $\begin{array}{l}\text { Express sadness and cry immediately in a certain } \\
\text { situation (injection) }\end{array}$ & 0 & 2 \\
\hline \multicolumn{3}{|l|}{ Talking } \\
\hline Give orders & 0 & 3 \\
\hline Answer promptly to a question & 2 & 20 \\
\hline Talk about something or about themselves & 1 & 7 \\
\hline Give opinion on facts & 1 & 3 \\
\hline Ask questions & 0 & 15 \\
\hline \multicolumn{3}{|l|}{ Playing } \\
\hline Present & 3 & 28 \\
\hline \multicolumn{3}{|l|}{ Not responding to stimuli / requests } \\
\hline Absent & 3 & 28 \\
\hline Total of behaviors & 19 & 249 \\
\hline
\end{tabular}

Table 2 shows that level 2 behaviors were more frequent before the therapeutic play session. In the category "moving", the most frequent behavior was changing position ( 9 children) before and after the therapeutic play session (4 children). In the category "gazing", before the therapeutic session, looking at someone or something moving was observed (12 children); the same was observed after the therapeutic play session (7 children). In the category "expressing emotions" before the therapeutic play session, sadness with crying was observed (4 children); no such behavior was seen after the therapeutic play session. In the category "talking", before the therapeutic play session, children answered questions in a low voice (18 children), and after the therapeutic play session, this behavior was similar.

Although the behaviors at this level generally do not change significantly before and after the therapeutic play sessions, the amount of any same behavior was significantly decreased before or after a therapeutic play session.

Children were found to migrate from level 1 to level 3 after a therapeutic play session; we highlight "moving" activities after a therapeutic play session, in which children changed positions (25 children), moved with a specific purpose (17 children), and carried out actions with specific aims (13 children), which were not observed before. "Gazing" after a therapeutic play session showed that children carefully observed what they saw (25 children) and fixed their eyes on someone or something (19 children); gazing before consisted of carefully observing what they saw (3 children). And in "talking", after the therapeutic play session, children responded readily to questions (20 children) and sometimes talked about something or themselves (7 children); these actions were scarcely observed before the session (Table 3).

\section{DISCUSSION}

Play is essential for development because it generates a proximal developmental zone: when playing, children behave beyond their usual behavior for their age; it is as if they were older than reality. Play includes all developmental trends in a condensed form, providing ample structuring for changes in needs and awareness. Children learn to act within a cognitive, rather than an external visual sphere; play fosters the development of abstract thought by creating an imaginary situation ${ }^{(26)}$.

Play is the first normal activity of the child's mind; according to Aberastury, "constant inhibition of children against play in childhood may be the only symptom of severe neurosis"(27). The way children play indicates their personal status ${ }^{(28)}$.

The essential feature of child play is not contained in the material or any results, but in the subjective activity during play, which is an experience of an intense and specific pleasure that justifies the need for play in children ${ }^{(29)}$.

Diseases and hospitalization are one of the main crises in the lives of children; several papers described and highlighted the impact of such events on children and their families. This situation becomes especially critical in young preschool children who, because of their development and short life experience, apply their imagination to discover why they are going through these situations ${ }^{(18)}$.

Therapeutic play was structured to relieve the anxiety children feel because of atypical experiences for their age, situations that tend to be threatening and may require more than recreation to dissolve anxiety; it should be used whenever children find it difficult to understand or deal with the event ${ }^{(23)}$.

Therapeutic play is important in nursing care because it may foster a positive response to a painful procedure after behaviors or responses are demonstrated in play ${ }^{(30)}$.

The physical and emotional condition of children at hospitalmayresult inloss ofinterestfor play; such children tend to lose the ability to play spontaneously ${ }^{(31)}$. 
In being admitted, children find themselves double sick: not only is there a physical disease, but there is also hospitalization that, if not adequately dealt with, will leave permanent scars in the child's mental health. Hospitalization is a world of mystery and terror for preschool children; at this age, they are unable to deal with abstract thinking, such as the temporal nature of facts and cause and effect relations. Hence, this experience is difficult to understand ${ }^{(9)}$.

Disease and hospitalization are important crises in the life of children; these events are a change in the usual state of health and environmental routine. The effects of hospitalization become even more harmful when children and their families are not appropriately prepared beforehand for a hospital stay and therapy ${ }^{(2)}$.

When in hospital, children have their domestic needs to which are added those related to the disease and hospitalization. Play is one of these needs; if not adequately met, behavioral disorders may ensue ${ }^{(32-33)}$.

Therapeutic play is a structured play for children to dispel the anxiety generated by atypical and potentially threatening experiences for their age that require more than recreational play to deal with the resulting anxiety. Therapeutic play should be applied whenever children find it difficult to understand or deal with a harsh experience, or when they need to be prepared for medical procedures ${ }^{(23)}$. It helps relieve stress after such procedures, as children dramatize the experience and handle the representative toy objects or instruments that were used ${ }^{(20-21)}$.

Therapeutic play sessions with hospitalized preschool children revealed that play fostered the expression of feelings; it is important for an adult to be present and to provide acceptance at these moments, so that children may externalize such feelings. We also concluded that even a single session of contact and play with children was more effective ${ }^{(7)}$.

Therapeutic play with preschool children in the first two days of hospital stay showed that participants presented behaviors more appropriate with their development (adaptation and stronger ego) as compared to children that did not play ${ }^{(9)}$.

It is known that, aside from recreation, stimulation, socialization and others, play is also important for representation, which provides relief or purification for subjects. Thanks to this function, play has a curative function because of its "escape valve" function as reducer of anxiety, as well as making it possible to diagnose any conflict the child may be experiencing. Research on therapeutic play by nurses strengthen the positive results attained by its use, demonstrating its importance for children during hospitalization and a growing effort to include this activity as an intervention strategy in the daily activities of nurses ${ }^{(5,34-36)}$.
The present study showed that there were fewer behaviors before compared with after a therapeutic play session, and that the behaviors of children within the categories (moving, gazing, expressing feelings, and talking) before a therapeutic play session were mostly levels 1 and 2, migrating to level 3 after the therapeutic play session. These observed behaviors show that this strategy is effective for reducing the trauma and stress of hospitalization for children and their families.

Our data revealed that children did not respond to stimuli and requests before therapeutic play sessions, and that after such sessions this situation was reverted. Furthermore, play was absent before therapeutic play sessions, but was maintained even after the session was over.

\section{CONCLUSION}

We concluded that play is essential in a pediatrics unit; it is the language that children know, and through which they may represent their positive or negative emotions, allowing us to better understand their world.

\section{REFERENCES}

1. Rossi Junior A, Aoshima DE. Controle da transmissão de infecções no ambiente hospitalar. In: Marcondes E, Vaz FAC, Ramos JLA, Okay Y. Pediatria básica: pediatria clínica geral. ga ed. São Paulo: Savier; 2003. p. 88-91.

2. Oliveira GF, Dantas FDC, Fonseca PN. 0 impacto da hospitalização em crianças de 1 a 5 anos de idade. Rev SBPH. 2004;7(2):37-54.

3. Erikson EH. Infância e sociedade. Rio de Janeiro: Zahar; 1971.

4. Whaley LF, Wong DL. Enfermagem pediátrica. Rio de Janeiro: Guanabara Koogan; 1989

5. Horta ALM. Influências do tipo de abordagens para injeções intramusculares nas reações de pré-escolares. Rev Esc Enferm USP. 1989;23(2):148-63.

6. Guimarães RN, Maia EBS, Ribeiro CA. 0 brinquedo terapêutico como instrumento no preparo da criança para medicação intratecal [abstract] 2001. [Presented at the State of Sao Paulo Congress of Pediatric Nursing; 2001; Campinas, SP].

7. Ribeiro CA, Maia EBS, Sabatés AL, Borba RIH, Rezende MA. 0 brinquedo e a assistência de enfermagem à criança. Enferm Atual. 2002;24(2):7-17.

8. Green CS. Understanding children's needs trough therapeutic play. Nursing. 1974;4(10):31-2.

9. Angelo M. Brinquedo: um caminho para a compreensão da criança hospitalizada. Rev Esc Enferm USP. 1985;19(3):213-23.

10. Pinheiro MCD, Lopes GT. A influência do brinquedo na humanização da assistência de enfermagem à criança hospitalizada. Rev Bras Enferm. 1993;46(2):117-31.

11. Ribeiro CA. Crescendo com a presença protetora da mãe e o terror da hospitalização [thesis]. São Paulo: Universidade de São Paulo, Escola de Enfermagem; 1999.

12. Ramsey NL. Effects of hospitalization on the child and the family. Child and family: concepts of nursing practice. New York: McGraw Hill; 1982.

13. Martins MR. 0 efeito do brinquedo terapêutico sobre o comportamento da criança submetida à cirurgia eletiva [thesis]. São Paulo: Universidade Federal de São Paulo, Departamento de Enfermagem; 2001. 
14. Freiberg KH. How parents react when their child is hospitalized. Am J Nurs. 1972; $72(7): 1270-2$.

15. Furiato RC. Uma vivência de brinquedo terapêutico no ambiente hospitalar. Pediat Atual. 1977;10(5):18-21.

16. Ribeiro CA. Sentindo o valor das experiências significativas para a aprendizagem: relato de duas situações vividas com crianças hospitalizadas. Rev Esc Enferm USP. 1983;17(3):159-203.

17. Almeida FA, Ângelo M. Brinquedo terapêutico: comportamentos manifestados por crianças em unidade de recuperação pós-operatória de cirurgia cardíaca. Rev Paul Enferm. 2001;20(1):5-12.

18. Borba RIHM. Utilização do brinquedo na assistência da criança hospitalizada: relato de experiência [abstract]. 1999. [Presented at the Brazilian Congress of Nursing; 1999; Florianópolis, SC].

19. Guimarães RN, Maia EBS, Ribeiro CA. 0 brinquedo terapêutico como instrumento no preparo da criança para medicação intratecal [resumo]. 2001. [Apresentado no Congresso Paulista de Enfermagem Pediátrica; 2001; Campinas, SP].

20. Ribeiro PJ, Sabates AL, Ribeiro CA. A utilização do brinquedo terapêutico como instrumento de intervenção de enfermagem no preparo de crianças submetidas à coleta de sangue [resumo]. Anais 1999; [Apresentado no Congresso Brasileiro de Enfermagem; 1999; Florianópolis, SC].

21. Nightingale F. Notas sobre a enfermagem: o que é e o que não é. São Paulo: Cortez; 1989.

22. Martins MR, Ribeiro CA, Borba RIH, Silva CV. Protocolo de preparo da criança pré-escolar para punção venosa, com utilização do brinquedo terapêutico. Rev Latino-Am Enf. 2001;9(2):76-85.

23. Barton PH. Nursing assessment and intervention through play. Current concepts in clinical nursing. Saint Louis: Mosby; 1969.
24. Clatworth SM. The effect of therapeutic play on the anxiety behaviors of hospitalized children [tesis]. Boston: University Microfilms International, University School of Educations; 1978.

25. Ribeiro PJ, Sabatés AL, Ribeiro CA. Utilização do brinquedo terapêutico como um instrumento de intervenção de enfermagem no preparo de crianças submetidas a coletas de sangue. Rev Esc Enferm USP. 2001;35(4):420-8.

26. Steele S. Child health and the family: Concept of communication. New York: Masson; 1981.

27. Moraes E. Estudantes de enfermagem assistem crianças doentes utilizando "entrevista com brincadeiras". Rev Esc Enferm USP. 1979;13(1):29-39.

28. Martins DMR. Assistência de enfermagem a crianças hospitalizadas, quando enfrentam situações desagradáveis. Rev Esc Enferm USP. 1979;13(2): $157-69$.

29. Vygostsky MT. 0 brinquedo e a assistência de enfermagem à criança. Rev Enferm Atual. 2002;24(2):7-17.

30. Freud S. Além do prazer. Rio de Janeiro: Imago; 1975.

31. Aberastury A. A criança e seus jogos. Porto Alegre: Artes médicas; 1992.

32. Machado DVM. 0 brinquedo e suas funções. Anais Nestlé. 1977;100(1):54-8.

33. Mash JB, Dickens M. Armstrong and Browder's nursing care of children. Philadelphia: Davis; 1973.

34. Green CS. Understanding children's needs trough therapeutic play. Nursing. 1974;4(10):31-2.

35. Robertson J. Some responses of young children to the loss of maternal care. Nurs Times. 1983;49(16):882-6.

36. Maria EBS, Guimarães RN, Ribeiro CA. 0 significado da medicação intratecal para a criança pré-escolar expresso em sua brincadeira. Rev Paul Enferm. 2003;22(3):268-77. 